\title{
TABES DORSALIS AND PERFORATED DUODENAL ULCER
}

\author{
J. P. Lawson, M.B., Ch.B. \\ Late Senior House Officer in Medicine, Crumpsall Hospital, Manchester \\ Senior House O.ficer in Radiology, David I.ewis Northern Hospital, Liverpool 3
}

IT is well recorded that tabes dorsalis can mask serious visceral disease. Wilson (1954) mentions that tabes can disrupt nervous pathways so as to produce a visceral analgesia capable of masking serious abdominal disease.

Connor (1910) published a case of a brakeman, aged 42, who died in hospital following an acute febrile attack and vomiting. There had been no abdominal pain, tenderness or rigidity to explain the condition but autopsy revealed a perforated appendix abscess and peritonitis.

Hanser (1919) recorded the case of a tabetic previously unknown to him who although having no abdominal signs or symptoms was found at autopsy to have a peritonitis caused by a perforated duodenal ulcer.

Sternberg (1929) described 12 cases of painless pneumonia and pleurisy in tabetics.

Grimble and Csonka (1952) published a case of a 59-year-old man known to have tabes, who was being treated for congestive heart failure due to syphilitic aortitis. Death followed a sudden deterioration, and autopsy revealed a perforated chronic gastric ulcer and peritonitis, although at all times abdominal signs and symptoms had been absent.

Doyle and Campbell (1953) described the case of an obese male aged 68 who first attended the hospital with leukoplakia of the cheek and was found to have clinical tabes. He was later admitted with acute retention of urine, thought to be due to a carcinoma of the prostate, and died the following day. At all times he was quite free from abdominal pain and abnormal abdominal signs although post-mortem examination revealed the presence of a generalized $B$. coli peritonitis and a perforated chronic gastric ulcer.

\section{Case Report}

History. J.S., an unemployed labourer aged $5 \mathrm{I}$, was admitted to Crumpsall Hospital via the casualty department on August 9, 1959. Two hours before admission he had developed a sudden attack of pain between the shoulder blades whilst standing in a bus queue. This was shortly followed by a bout of vomiting and sweating. There was no dyspnœa, pain in the chest or abdominal pain. The patient was able to make his own way home on foot.

At home he took a Sedlitz powder, which was followed by three further attacks of vomiting and four loose bowel actions. There was no blood in either vomitus or fæces. The pain spread to both shoulder tips, where it persisted and was the cause of his attendance at the casualty department.

Four years previously he had developed a similar attack of sweating and stated that he had also vomited blood. At this time he was apparently found to be suffering from pulmonary tuberculosis, and was transferred to a sanatorium. Treatment was commenced with streptomycin, PAS and INH. He was a difficult patient and in all was admitted to, and took his own discharge from, four different sanatoria, finally taking his own discharge before treatment was completed.

He was quite emphatic that he had never suffered from any form of chest or abdominal pain, although periodic attacks of nausea and vomiting had occurred. He had not noticed that they were related to food.

At the time he denied having had any venereal infection. Later he admitted that he may have had an infection whilst in Cyprus during the last war, but he was not treated at the time and apparently had not had any specific anti-syphilitic treatment for any stage since.

\section{Examination}

A well-built unkempt man. Skin: clammy, but no pallor. Teeth: dirty and decayed. Throat: clear. Tongue: not furred. No glands palpable. Temperature: $98.6^{\circ} \mathrm{F}$. At no stage in the examination did he complain of, or appear to be in, any pain.

C.V.S. Pulse $120 / \mathrm{min}$, regular. B.P. $85 / 70$.

R.S. Respiration regular, $20 / \mathrm{min}$. Apical crepitations present right and left.

Abdomen. No distension, tenderness or guarding. Bowel sounds were present. The bladder was palpable to the umbilicus and was not tender; urine could be expressed by manual pressure. Rectal examination was normal.

C.N.S. Cranial nerves. Pupils: anisocoria was present. Both were irregular but not constricted. Both failed to react to light, but reacted to accommodation. Other cranial nerves intact. Spinal nerves. There was no obvious change in tone or power. Marked ataxia was present on testing by the finger-nose and heel-knee tests. Reflexes: the lower limb and abdominal reflexes were absent. There was loss of position sense, vibration sense and light touch below the level T 5-6. Sensation 
to pin-prick was greatly reduced below this level. There was no pain on squeezing the Achilles tendon. Marked Rombergism was present.

At this stage a clinical diagnosis of tabes dorsalis was made but there was nothing abnormal found in the abdomen to explain the patient's condition.

\section{Investigations}

$\mathrm{Hb}$ on admission $\quad$.. $12.0 \mathrm{~g} . / 100 \mathrm{ml}$.

Four hours later.. $\quad$.. $\quad 11.4 \mathrm{~g} . / 100 \mathrm{ml}$.

Serum urea $\quad \ldots \quad \quad \ldots \quad 38 \mathrm{mg}$. $/ 100 \mathrm{ml}$.

$\mathrm{Na} \quad$.. $\quad \ldots \quad \mathrm{I} 29 \mathrm{mEq} . / \mathrm{l}$.

K.. $\quad \cdots \quad \quad \cdots \quad 5$ mEq. $/ 1$.

Cl $\quad \ldots \quad \quad \ldots \quad 96 \mathrm{mEq} . / 1$.

Amylase .. . . 60 Street-Close units

(normal 9-35 units/100 ml.)

ECG showed a sinus rhythm with occasional ventricular premature beats and was otherwise normal.

$\mathrm{X}$-ray chest showed a marked infiltration of both apices. There was no evidence of mediastinal emphysema and no evidence of pneumothorax.

Unfortunately, at this stage he was not fit enough to radiograph in the upright position to determine whether or not gas was present under the diaphragm and radiographs in the lateral recumbent position using a horizontal tube were not taken.

\section{Management}

The patient was admitted to the ward for symptomatic treatment of his shocked state. Throughout the following hours his clinical condition did not improve despite intravenous blood transfusion. Early the following morning his blood pressure had fallen to $70 / 50$ and there had been an increase in his sweating. At this stage his abdomen was found to be free from all tenderness and guarding. He was seen on this occasion by the Senior Surgical Registrar who could find nothing in the abdomen to explain the condition.

Although the symptomatic treatment was continued, there was little improvement in the patient's condition, and when next examined, it was observed that his abdomen was becoming distended, the liver dullness was diminished and there was shifting dullness present in the abdomen. There was no abdominal tenderness or rigidity. The bowel sounds were diminished.

At this stage it was decided that a laparotomy should be performed. This was performed by Mr. M. A. Brennan. The patient was considered well enough for a general anaesthetic.

The peritoneal cavity contained over two pints of fibrinous exudate and there was an obvious peritonitis. In the anterior wall of the first part of the duodenum there was a perforated ulcer, over I $\mathrm{cm}$. in diameter. The perforation was repaired by omental grafting. and suturing, and the abdomen was closed. Following this he made a somewhat stormy but satisfactory recovery.
The following investigational results support the clinical diagnosis of tabes dorsalis.

C.S.F.: manometrically normal; clear colourless fluid; cells 3 erythrocytes, 35 leucocytes predominantly lymphocytes; protein $32 \mathrm{mg} . \%$; globulin no excess; Lange zero in all dilutions; W.R. positive. Blood Wasserman, Reiter protein complement fixation, treponemal immobilization tests all positive.

He was referred to the Manchester Chest clinic for assessment of his pulmonary tuberculosis, where it was found that his sputum was free from A.F.B. and his clinical and radiographic condition unchanged from his previous attendances. He is at present being kept under observation as an out-patient.

He also attended Ancoats hospital for his neurosyphilis. He was given Procaine Penicillin, 600,000 units daily for ten days and then threeweekly injections each of 1.2 m.u. Penidural. $\mathrm{He}$ then defaulted.

Post-operative Barium studies were not performed as he failed to keep his appointment at Crumpsall hospital.

\section{Discussion}

The percentage of cases of tabes dorsalis with co-existent gastric or duodenal ulcer is very difficult to estimate and great variation is found in the series of various authors.

Bockus (1950) maintained the incidence of peptic ulcer in neurosyphilis is no greater than the population as a whole and puts the figure at $8 \%$ but he did not define the population studied.

Crohn (1921), although not giving any figure for the association, called attention to the fact that -. . coexistent with the easily recognized and familiar picture of tabes we may be and possibly often are treating a fully developed gastric or duodenal ulcer .... and it is possible that peptic ulcer is a frequent concurrent of tabes'. 'He suggested that the gastric ulcers are 'trophic' in origin and that the involvement of the nervous system might predispose to ulcer formation by giving rise to hypersecretion, quoting that $33 \%$ of cases of continuous hypersecretion are accompanied by ulcers. Most authoritative articles now show that duodenal ulcers are accompanied by hypersecretion and gastric ulcers by normal levels of secretion (Levin, Kirshner and Palmer 1948). In addition Crohn and Wilensky (1917) called attention to the frequent disturbance of gastric motility associated with gastric crises. That delayed emptying predisposes to ulcer and causes retarded healing in experimental dogs has been shown by Friedman and Hamburger (1914).

On the other hand Hunt and Lisa (I93I) stated that the combination of ulcer and tabes is un- 
common, although they do not state the number of cases studied and illustrate their paper by four cases only.

Fremont-Smith and Ayers (I925) studied 50 cases of neurosyphilis in which gastric symptoms were prevalent. In five cases a definite pathology (four cases of peptic ulcer, one case of gastric carcinoma) was shown by operation or X-ray examination. At autopsy Exner and Schwartzmann (I9I2) found five cases of peptic ulcer and three cases of gastric carcinoma in 75 tabetics.

In an analysis of the Mayo clinic records of 200 syphilitics who complained of 'stomach trouble' ( $87 \%$ as their chief complaint) Stokes and Brown, quoted by Stokes, Beerman and Ingraham (1944), found that $10 \%$ had organic lesions of the gastrointestinal tract. Gumma of the stomach accounted for $4 \%$ of the 200 .

In a recent paper Valdes, Cervero and Clariana (1954) commented on the wide variation amongst authors in figures given for the incidence of gastric pathology, both syphilitic and due to other disease processes in tabes dorsalis.

It has been stressed for a long time that a gastrotabetic crisis can mimic an acute abdominal emergency resulting in a needless laparotomy. Nuzum (1916) stated that ' negligent ' examination accounted for 97 needless laparotomies in 1,000 tabetics, while Woltman (1924) reported 63 needless laparotomies in a series of 120 gastric crises. Stokes and Brown in their analysis of the Mayo clinic records found that $18 \%$ of the syphilitics who complained of ' stomach trouble ' had needless laparotomies, and Stokes with Ingraham and Beerman (1944) described a patient whose abdomen carried five laparotomy scars (performed prior to his seeing him) as a woeful record of unnecessary operations for gastric crises.

In the current edition of their textbook Cecil and Loeb (1959) state, "The differential diagnosis of acute perforation is rarely difficult. Biliary, renal and intestinal colic lack the board-like rigidity... in gastro-tabetic crisis the abdominal rigidity is usually absent'. Harrison (1958) reminds us that 'patients with gastric crises are sometimes diagnosed as having acute surgical conditions and unnecessary operations have been performed . . . abdominal rigidity is usually absent in the gastric crises of tabes dorsalis, Price (1956) and Conybeare and Mann (1957) both emphasize that a gastro-tabetic crisis can mimic a perforated ulcer.

However, with the emphasis on failing to recognize a gastro-tabetic crisis in a patient, there is the greater danger that a perforated peptic ulcer or other abdominal emergency in a tabetic subject will be missed, particularly if the signs of an acute abdominal condition are masked. Aird (1957) remarks that 'A perforated peptic ulcer occurring in a tabetic subject may offer periodic difficulties. The abdominal muscles may be incapable of real rigidity and the presence of the signs of tabes may lead the clinician to blame a gastric crisis for the abdominal pain'

According to Bockus (1950) visceral pain is probably conveyed by three mechanisms.

I. True visceral pain which is conducted by the sympathetic nervous system; in the case of the stomach this is via the greater splanchnic nerves (root values T6-9). This pain is usually midline and occurs after the appropriate stimulus is applied, e.g. distention of a hollow viscus, spasm or anoxæmia.

2. Referred pain. The mechanism of this pain is still unsettled but the sensory impulses travel by way of the sympathetic nerves to the spinal cord and are communicated via the sensory nerves of the same cord segment to the appropriate somatic dermatome. The pain is usually sharp and well localized.

3. Purely by somatic nerves, the nerve endings of which lie in the parietal peritoneum. Morley (1937) has named this the 'Parieto-cutaneous reflex'. In the abdomen it is associated with muscular guarding and rigidity. This mechanism explains the classical shoulder-tip pain of diaphragmatic irritation.

Bentley and Smithwick (1940) investigating the effect of sympathectomy on hypertensives found that the visceral pain caused by distending a balloon in the jejunum before sympathectomy was abolished on the side of the sympathectomy. Bingham, Inglefinger and Smithwick (1950) found the pain to be reduced but more widespread on the side of the splanchnicectomy, the pathways of which did not regenerate. They also found that tenderness persisted in the absence of pain but that the 'peritoneo-cutaneous reflex' was abolished only by local nerve block.

In this patient it is thought that the true visceral pain pathway was interrupted by the syphilitic process. This would explain the absence of abdominal pain through the years when the ulcer must have been present, and it is interesting to note that the periodic vomiting may well have been the sole symptom of this man's peptic ulceration. However, absence of pain when a duodenal ulcer is present can occur in normal people although this is uncommon. The fact that he perforated without abdominal pain, rigidity and guarding suggests that the somatic nerves involved in the 'parieto-cutaneous reflex' had also been involved in the process. It is probably significant that, a somatic sensory level occuring at $\mathrm{T}_{5}-6$, the abdominal pain and signs were absent while the classical shoulder-tip pain 
$\left(\mathrm{C}_{3}-5\right)$ was the cause of the patient presenting himself at the casualty department.

Most modern authors on visceral pain suggest that somatic nerve involvement is required before the pain of perforation is abolished. Alvarez (193I) however, discussed splanchnic nerve section for the relief of abdominal pain, particularly in peptic ulceration, and advised against this because of the danger of silent perforation.

Because of the patient's clinical condition he was never X-rayed for gas under the diaphragm, which would have given the clinical diagnosis much earlier, and it is suggested that this examination should be performed in all tabetics with signs of unexplained shock. If the patient is not well enough to X-ray in the erect position an $\mathrm{X}$-ray taken with the tube horizontal and the patient lying on his side may well show free peritoneal gas (Feldman, I957).

\section{Summary}

I. A case of perforated duodenal ulcer which lacked the usual abdominal signs and symptoms is described in a patient suffering from tabes dorsalis. 2. A series of similar cases revealed at autopsy is reviewed.

3. The incidence of peptic ulceration occurring in cases of neurosyphilis is variable and the figures of some authors are quoted. Emphasis has long been laid on unnecessary laparotomies being performed on tabetics but attention is not drawn to the same extent to tabes producing visceral analgesia and masking the signs and symptoms of an abdominal catastrophe. The analgesia in these cases is discussed in the light of the known mechanisms of visceral pain.

4. The value of radiographing for gas under the diaphragm in tabetics with signs of shock is stressed.

\section{Acknowledgments}

I would like to thank Dr. D. W. Macartney and Mr. H. A. Simmons for allowing me to report this case, and Dr. D. A. Price-Evans for his constructive criticism and encouragement.

\section{REFERENCES}

AIRD, I. (1957): ' A Companion in Surgical Studies', 2nd ed., p. 736. Edinburgh and London: E. \& S. Livingstone.

Alvarez, W. C. (1931): Abdominal Pain. Paths over which it Travels and Ways in which These may be Blocked, Amer. F. Surg., 14, 385 .

Bingham, J. R., INGLEfinger, E. J., and Smithwick, R. H. (I950): The Effects of Sympathectomy on the Motility of the Human Gastro-intestinal and Biliary Tracts, Gastroenterology, 15, 6.

Bentley, F. H., and Smithwick, R. H. (1940): Visceral Pain Produced by Balloon Distension of the Jejunum, Lancet, ii, 389 .

BockUS, H. L. (1950): ' Postgraduate Gastroenterology', p. 148. Philadelphia: J. B. Saunders.

Cecil, R. L., and Loeb, R. F. (1959): 'A Text-book of Medicine', roth ed., p. 7r2. Philadelphia and London: J. B. Saunders.

Connor, L. A. (1910): Visceral Anæsthesia in Tabes, F. Amer. med. Ass., 55, 1427.

Conybeare, Sir John, and ManN, W. N. (1957): "Textbook of Medicine ', i2th ed., p. 674. Edinburgh and London: E. \& S. Livingstone.

Crohn, B. B. (1921): The Existence of Gastric Ulcer with Tabes Dorsalis, Y. Amer. med. Ass., 77, 2023.

- , and WILENSKY, A. O. (1917): Studies in the Variations in the Tonus of the Gastric Musculature in Health and Disease, Arch. intern. Med., 20, 145.

Doyle, J. O., and Campbell, D. J. (1953): Masked Perforation of a Gastric Ulcer in a Case of Tabes Dorsalis, Brit. F. vener. Dis., 29, 164.

Exner, A., and Schwartzmann, E. (1912): Tabische Krisen, Ulcus ventriculi und Vagus, Wein. Klin. Wschr. (1912), No. 48 .

Feldman, M. (1957): ' Clinical Røntgenology of the Digestive Tract', 4th ed. Baltimore: Williams \& Wilkins.

Fremont- Smith, M., and Ayers, J. B. (1925): The Gastro-intestinal Symptoms of Neuro-syphilis, F. Amer. med. Ass., $85,1282$.

Friedman, J. C., and Hamburger, W. W. (1914): Experimental Chronic Gastric Ulcer, Ibid., $63,380$.

Grimble, A. S., and CsonkA, G. W. (1952): Visceral Analgesia-A Case of Masked Abdominal Catastrophe in Tabes Dorsalis, Brit. F. vener. Dis., 28, $6 \mathrm{r}$.

HANSER, A. (1919): Viszerale Analgesie der Tabischen, Dtsch. med. Wschr., 45, 129.

HaRRISON, T. R. (1958): 'Principles of Internal Medicine', 3rd ed., p. 974. New York; Blackiston.

Hunt, E. L., and Lisa, J. R., (r93 I): Peptic and Duodenal Ulcer in Tabes Dorsalis, F. Amer. med. Ass., 96, 95.

Levin, E., Kirshner, J. B., and PALMER, W. L. (1948): Nocturnal Gastric Secretion, Arch. Surg. (Chicago), 56, 345-356.

Morley, J. (1937): Visceral Pain, Brit. med. Y., ii, 1270.

Nuzum, J. W. (I916): Needless Surgical Operations from Failure to Recognize Tabes Dorsalis, F. Amer. med. Ass., 66, 482 .

PrICE (1956): 'Textbook of the Practice of Medicine', edited by D. Hunter, 9th ed., p. 1465. Oxford Medical Publications.

SternberG, M. (1929): Die Pneumonie der Tabischen, Dtsch. Z. Nervenheilk, ro7, 97.

Stokes, J. H., BeErman, H., and Ingraham, N. B. (1944): 'Modern Clinical Syphilology', p. ror r. Philadelphia: J. B. Saunders.

Valdes, M., Cervero, R., and Clariana, S. (1954): Problemas que plantea en la clinica la co-existencia de ulcus y sifilis, Med. esp., 32, 380.

Wilson, S. A. K. (1954): ' Neurology', edited by Bruce, p. 522. London: Butterworth.

Woltman, H. W. (1924): The More Common Neurologic Disorders Associated with Pain and Encountered in General Diagnosis, Minn. Med., 7, 193 . 